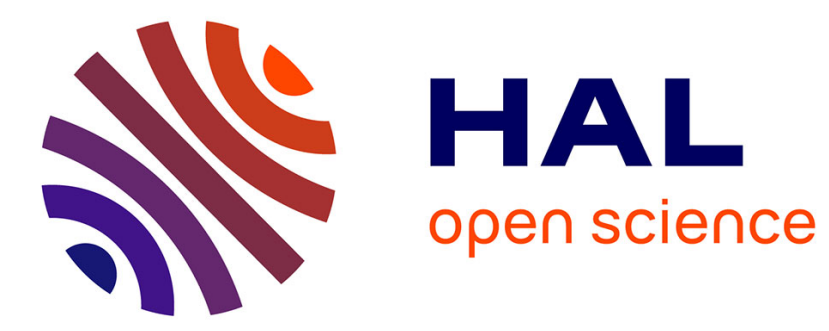

\title{
Can Rock-Eval pyrolysis assess the biogeochemical composition of organic matter during peatification?
}

Frédéric Delarue, Jean-Robert Disnar, Yoann Copard, Sébastien Gogo, Jérémy Jacob, Fatima Laggoun-Défarge

\section{To cite this version:}

Frédéric Delarue, Jean-Robert Disnar, Yoann Copard, Sébastien Gogo, Jérémy Jacob, et al.. Can Rock-Eval pyrolysis assess the biogeochemical composition of organic matter during peatification?. Organic Geochemistry, 2013, 61, pp.66-72. 10.1016/j.orggeochem.2013.06.004 . insu-00837683

\section{HAL Id: insu-00837683 \\ https://hal-insu.archives-ouvertes.fr/insu-00837683}

Submitted on 10 Jul 2013

HAL is a multi-disciplinary open access archive for the deposit and dissemination of scientific research documents, whether they are published or not. The documents may come from teaching and research institutions in France or abroad, or from public or private research centers.
L'archive ouverte pluridisciplinaire HAL, est destinée au dépôt et à la diffusion de documents scientifiques de niveau recherche, publiés ou non, émanant des établissements d'enseignement et de recherche français ou étrangers, des laboratoires publics ou privés. 


\section{Can Rock-Eval pyrolysis assess the biogeochemical composition of organic matter during peatification?}

Frédéric Delarue ${ }^{1,2,3 *}$, Jean-Robert Disnar ${ }^{1,2,3}$, Yoann Copard $^{1,2,3,4}$, Sébastien Gogo $^{1,2,3}$, Jérémy Jacob ${ }^{1,2},{ }^{3}$ Fatima Laggoun-Défarge ${ }^{1,2,3}$

${ }^{1}$ Université d'Orléans, ISTO, UMR 7327, 45071 Orléans, France

${ }^{2}$ CNRS/INSU, ISTO, UMR 7327, 45071 Orléans

${ }^{3}$ BRGM, ISTO, UMR 7327, BP 36009, 45060 Orléans, France

${ }^{4}$ Université de Rouen, M2C, UMR CNRS 6143, ,76821 Mont Saint Aignan, France

*Corresponding author: Tel.: +332384946 60; fax: +332 38494476

E-mail: frederic.delarue@univ-orleans.fr

\section{Abstract}

Understanding the responses of soil organic carbon to an increase in global temperature is crucial to estimate potential feedbacks on global warming. In such a context, Rock-Eval pyrolysis has been recently proposed as a screening tool to investigate soil organic matter (SOM) chemistry and vulnerability. In order to test the validity of Rock-Eval as an indicator of SOM chemistry and of OM transformations, we compared classical Rock-Eval-derived parameters (Total Organic Carbon - TOC, Hydrogen Index - HI and Oxygen Index - OI) to Fourier infrared (FTIR) spectroscopy measured on peat sampled in two contrasted moisture conditions. The raise of TOC in the peat record depicted OM enrichment in aromatic moieties and lipids, whereas $\mathrm{HI}$ and $\mathrm{OI}$, respectively, depicted the decomposition of carbohydrates and decarboxylation during early decay processes. Thought to be complementary to the classical 
parameters, other indicators based on the pyrolysis curve (S2) gave redundant or contradictory results. As an example, SOM cracking around $450^{\circ} \mathrm{C}$ (namely the $\mathrm{F} 3$ component) was linked with carboxylic acids only in the dryer site. In the wetter one, no correlation was found between the F3 component and any FTIR absorption bands. This study underlined the current limitations of deconvolution-derived parameters for the characterization of the biochemistry of OM. Finally, our work suggested that the routine use of Rock-Eval pyrolysis must be always associated with another characterization tool of OM, as FTIR, to avoid misunderstanding.

\section{Introduction}

The rise of greenhouse gas concentrations in the atmosphere and the consequential increase of the Earth surface temperature is still a topic of debate (IPCC, 2007; Otto et al., 2013). Some large uncertainties remain in current projections of future climate as to the response of soil organic carbon (SOC) decomposition. Increased $\mathrm{CO}_{2}$ emission through accelerated SOC mineralization may act as a strong positive feedback to global warming (Davidson and Janssens, 2006). Among soil ecosystems, peatlands retain a specific attention since they contain about $455 \mathrm{Gt}$ of carbon, the equivalent of $30 \%$ of the global SOC stock (Gorham, 1991). Currently, its peculiar environmental conditions (water acidity, low temperature and anoxia) favor primary production rather than mineralization by microbial activities (Clymo, 1983). Because of this small imbalance, carbon accumulates for centuries or millennia leading to a strong carbon sink. In a context of climate change, environmental conditions are presumed to favor peat decomposition threatening peatland carbon storage (Dorrepaal et al., 2009). It is therefore crucial to estimate the future potential feedback of SOC on global warming by the evaluation of temperature sensitivity of the various pools of SOC (i.e. labile 
and recalcitrant) (Davidson and Janssens, 2006). Thus, experimentally techniques of SOM characterization are required to discriminate the different pools of OM. Saenger et al. (2013) pointed out the potential use of Rock-Eval (RE) pyrolysis as a routine method to investigate SOM vulnerability and its bulk chemistry. However, few studies dealt with the biogeochemical signification of the parameters derived from RE pyrolysis (Carrie et al., 2012).

RE pyrolysis was initially designed to estimate the petroleum potential of sedimentary rocks (Espitalié et al., 1985a, b; Lafargue et al., 1998; Sykes and Snowdon, 2002). This technique effectively provides information on the quality and quantity of $\mathrm{OM}$ of rocks and sediments from the thermal and pyrolytic release of volatile organic compounds, and carbon dioxide $\left(\mathrm{CO}_{2}\right)$ and carbon monoxide $(\mathrm{CO})$ released during temperature-programmed pyrolysis and a subsequent temperature-programmed oxidation phase. The measurements are used to calculate parameters such as Total Organic Carbon (TOC), the Hydrogen Index (HI) and the Oxygen Index (OI). The two latter parameters are used as proxies for $\mathrm{H} / \mathrm{C}$ and $\mathrm{O} / \mathrm{C}$ atomic ratios to assess the OM type and to track the evolution of OM diagenesis in pseudo-Van Krevelen diagrams (Feller et al., 2010).

More recently, RE pyrolysis was extended to the analysis of soils and sediments OM (DiGiovanni et al., 1998; Disnar et al., 2003). These indices were used to reconstruct paleoenvironments through the evolution of $\mathrm{OM}$ quality and quantity in sedimentary archives (Tamburini et al., 2003; Miras et al., 2004; Holtvoeth et al., 2005; Zaccone et al., 2011). New parameters essentially based on the pyrolyzate yields (S2 curve) recently emerged. For example, the R400 parameter is calculated as the ratio between the amounts of pyrolyzate compounds generated under $400{ }^{\circ} \mathrm{C}$ compared to total pyrolyzate yield (Disnar et al., 2003). The R330 parameter was defined similarly to selectively take into account the OM components that decompose first (Delarue et al., 2011). The rationale for these two indices is 
that the compounds emitted under $400^{\circ} \mathrm{C}$ are biopolymers (polysaccharides, lignin...) and those pyrolysed before $330^{\circ} \mathrm{C}$ are the most thermo-labile ones $\left(<330^{\circ} \mathrm{C}\right)$. Parameters such as R400 and R330 arbitrarily divide the S2 signal into following well defined temperature limits but without precisely taking into account the shape of the S2 emission curve that as for long been proven to be multi-lobed for thermally immature OM (Disnar and Trichet, 1984). The various S2 curve lobes correspond to the successive cracking of several organic moieties, each producing a pseudo-Gaussian pyrolysate curve that reflects a rather homogeneous thermal stability. Consistently, mathematical deconvolution was performed on S2 signals to produce a set of individual Gaussian curves interpreted as representative of pyrolytic fractions related to the successive cracking of organic compounds of coherent thermal stability such as fresh plant constituents, soil litter, humic-like substances and refractory OM (Hetenyi et al., 2005). Previous work used RE pyrolysis to describe the various OM pools and their fate through meta-analyses of soil horizon (Disnar et al., 2003; Sebag et al., 2006). In these works, the first components of the S2 signal was attributed to biochemical components and the latter to humic substances without attempting a more detailed attribution. Recently, Carrie et al. (2012) used pure biochemical compounds and biological standards to understand RE analysis parameters in order to test the biogeochemical signification of RE-derived parameters. Although this is a notable step in the understanding of the biogeochemical significance of RE parameters, this work did not take into account physico-chemical links between the wide range of $\mathrm{OM}$ pools that may change depending on biological sources of $\mathrm{OM}$ and on the impact of stabilization processes.

The aim of the present paper was to test the pertinence of RE pyrolysis indices. This was performed comparing the OM characterization by RE pyrolysis and by Fourier Transform Infrared (FTIR) spectroscopy of recent peat sequences taken from two contrasted moisture sites, only separated by few meters, in the "Le Forbonnet" peatland. 


\section{Material and methods}

\subsection{Study site and sampling}

The Forbonnet peatland (46 $49^{\prime} 35^{\prime \prime} \mathrm{N} ; 6^{\circ} 10^{\prime} 20^{\prime \prime} \mathrm{E}$, altitude $836 \mathrm{~m}$ a.s.l.) is an undisturbed ombrotrophic Sphagnum-dominated mire situated in eastern France, in the French Jura mountains (Jassey et al., 2011). Cold winters (on average $-1.4^{\circ} \mathrm{C}$ ) and mild summers (on average $14.6^{\circ} \mathrm{C}$ ) characterize the site. The annual mean temperature measured at the site was $6.5^{\circ} \mathrm{C}$ and the annual mean precipitation was $1200 \mathrm{~mm}$.

Two adjacent sites were selected in the peatland: the first site is an open bog, named "bog", characterized by mixed vegetation (Eriophorum vaginatum, Sphagnum fallax, $S$. magellanicum, and Vaccinium oxycoccus). The second site is a transitional poor fen, named "fen", characterized by smaller abundancies of E. vaginatum, the absence of $S$. magellanicum and Vaccinium oxycoccus, and a greater abundance of $S$. fallax and $S$. Rubellum when compared to the bog. The two sites also were distinguished by their microtopographic features. The bog site consisted in hummocks whereas the fen site was dominated by hollows and lawns. Accordingly, water level was lower in the bog site than in the fen site (see Delarue et al., 2011 for further details).

In each site, three peat cores of fifty centimetres long and thirteen centimetres in diameter were extracted in June 2008. Three samples were collected in the upper oxic part (acrotelm; at 2.5-5, 5-7.5 and 7.5-10 $\mathrm{cm}$ depth), three in the zone of fluctuation of the water level (mesotelm; at 12.5-15, 20-22.5 and 25-27.5 cm depth) and three in the anoxic part (catotelm, at $30-32.5,40-42.5$ and $47.5-50 \mathrm{~cm}$ depth). Samples were dried, crushed and then stored at $4^{\circ} \mathrm{C}$ before analysis. 


\subsection{Rock-Eval pyrolysis}

Analyses were carried out with a RE6 pyrolyzer "Turbo" model (Vinci Technologies) on ca. $30 \mathrm{mg}$ of powdered dry peat. The basic operating principles of this apparatus were presented in Lafargue et al. (1998). The samples first undergo a programmed pyrolysis (under $\mathrm{N}_{2}$ ) from 200 to $650^{\circ} \mathrm{C}$ at a rate of $30^{\circ} \mathrm{C} \mathrm{min}{ }^{-1}$, then the residue is oxidized under air in a second oven. The amounts of volatile compounds released at the start of the analysis and during the pyrolysis phase [S1 and $\mathrm{S} 2$, respectively; in mg hydrocarbons $(\mathrm{HC}) \mathrm{g}^{-1}$ ] are quantified by a flame ionisation detector; the $\mathrm{CO}$ and the $\mathrm{CO}_{2}$ released during the pyrolysis and oxidation phases $\left(\mathrm{S} 3 \mathrm{CO} / \mathrm{S} 3 \mathrm{CO}_{2}\right.$ and $\mathrm{S} 4 \mathrm{CO} / \mathrm{S} 4 \mathrm{CO}_{2}$, respectively) are quantified by online infrared detectors. The Rock-Eval parameters used for this study are the following ones: (i) Total Organic Carbon (TOC, wt $\%$ ) that accounts for the quantity of organic carbon present in the sample and is calculated by addition of the weighed amounts of all the effluents of pyrolysis and oxidation; (ii) the Hydrogen Index (HI, in $\mathrm{mg} \mathrm{HC} \mathrm{g}^{-1}$ of $\mathrm{TOC}$ ) that is the amount of hydrocarbon products released during pyrolysis (S2), normalized to TOC; (iii) the Oxygen Index (OI RE6, in $\mathrm{mg} \mathrm{O}_{2} \mathrm{~g}^{-1}$ of TOC) is similarly calculated from the amounts of $\mathrm{CO}_{2}$ and $\mathrm{CO}$ released during pyrolysis $\left(\mathrm{S}_{3} \mathrm{CO}_{2}\right.$ and $\left.\mathrm{S} 3 \mathrm{CO}\right)$, normalized to TOC. In this work, OI RE6 was simply named OI.

The R400 (Disnar et al., 2003) and R330 (Delarue et al., 2011) parameters represent the parts of the S2 signal respectively produced below 400 and $330^{\circ} \mathrm{C}$ (Fig. 1). S2 curves were also decomposed into elementary Gaussian components with peakfit software to infer OM pools (Fig. 1). The software automatically iterates (temperature position, shape, area) four Gaussian components initially randomly positioned (named F1, F2, F3 and F4 and corresponding to the 
successive cracking OM pools) until a good correlation with the initial $\mathrm{S} 2$ pyrolysis curve $\left(\mathrm{R}^{2}\right.$ $>0.99$ ) is obtained.

\subsection{Fourier Transform Infrared spectroscopy}

Spectral characterization of peat samples was performed by diamond attenuated total reflectance FTIR spectroscopy using a Nicolet Magna-IR 760 FTIR spectrometer fitted with a potassium bromide beam splitter and a deuterium triglycine sulphate detector. The dried and powdered peat was placed directly on a diamond crystal. Spectra were acquired by 128 scans at a $2 \mathrm{~cm}^{-1}$ resolution over the range $4000-750 \mathrm{~cm}^{-1}$. Corrections were made for each spectra taking into account differences in depth penetration of IR beam (Omnic software 7.2, Thermo Electron). Differences in the amplitude and baseline between samples were corrected by subtraction of the minimum absorption of the sample to the whole spectra followed by a multiplication, also applied on the whole spectra, to obtain a spectral maximal absorbance value of 1 for each peat sample. Relative intensities of each IR absorption bands then were calculated following Solomon et al. (2005) method to compare with RE pyrolysis parameters. The interpretation of IR absorption bands is summarized in Figure 2. All absorption bands between 1238 and $1654 \mathrm{~cm}^{-1}$ varied as 1513 and $1611 \mathrm{~cm}^{-1}$ absorption bands. We therefore focussed only on these latter.

\subsection{Statistics}

In order to compare previously described RE parameters and the relative intensities of each IR absorption band, a correlation matrix was performed ( $n=27$ for both bog and fen sites; level of significance, $p<0.05)$. 
Selection of the most relevant data to be processed in a multivariate analysis were done on the basis of the correlation matrix to avoid any redundancy and to improve the understanding of the biochemical signification of the RE variables. Principal component analysis (PCA) was therefore applied to the whole set of selected variables. Two factors (PCA1 and PCA2) with eigenvalues superior to 1 were retained. All statistics were performed with Statistica 98 software ${ }^{2}$.

\section{Results and Discussion}

\section{1. Biogeochemical signification of the TOC, OI and HI parameters}

The FTIR spectra of our peat samples exhibited all the peaks already described for peats from other areas (e.g. Artz et al., 2008). No evidence of any mineral signals was observed in any sample. Owing to this, any change in the FTIR spectra and RE-derived parameters could only be attributed to biochemical changes that occurred in the course of peatification, without any interaction with minerals inducing other possible carbon stabilization paths (von Lützow et al., 2007). Consequently, the studied peat samples constituted a case study to infer REderived parameter biochemical significance(s) by a simple and direct comparison with FTIR spectra. Additionally, as it was previously demonstrated (Delarue et al., 2011), for this

peatland, early decomposition of OM was mainly controlled by aerobic conditions ruled by water level changes. These led to higher OM decomposition in the bog site than in the fen one. Therefore, the comparison of RE-derived and FTIR parameters between the two sites should provide new insights on the impact of early $\mathrm{OM}$ decomposition processes and on their significance. 
PCA analysis showed that the first and second components explained 51.70 and 22.56 $\%$ of the variability for the bog site and 64.52 and $15.42 \%$ for the fen site (Fig. 3). The PCA biplots well discriminated samples from the acrotelm and those from the catotelm (Fig. 3). Therefore, the PCA1 axis reflected the impact of OM degradation occurring at depth, through early diagenetic processes. As an example, for both sites, the first axis was mainly dictated by TOC, which is known to be accumulated with depth in the peat record (Delarue et al., 2011; Fig. 4). As a consequence, the correlation of any other variable with TOC also indicated its increase with depth. On the other hand, anti-correlation with TOC can be assigned to a decrease of the considered parameter in the course of early diagenesis (Table 1; Fig. 4). Whatever the core, there were strong correlations between TOC and the 1513, 1611, 2850 and $2918 \mathrm{~cm}^{-1}$ IR absorption bands indicating the presence of carbon-rich moieties, namely aromatic and lipidic components (Table 1; Fig. 2). These relations revealed an accumulation or formation of such carbon-rich organic compounds during diagenesis while most of the functional groups (C-O and O-H mainly) were removed (Cocozza et al., 2003). The bryophyte genus Sphagnum does not synthesize lignin and is strongly enriched in polyphenols such as trans-sphagnum acid (Rasmussen et al., 1995; van Breemen, 1995). Owing to the predominance of Sphagnum species, most of the aromatic functional groups could here be attributed to polyphenols. The relative $\mathrm{C}$ enrichment was also explained by the loss of other components such as the easily degradable polysaccharides due to aerobic decomposition occurring in the first centimetres of the peat, as underlined by the anticorrelation between hemicellulosic/cellulosic compounds markers (IR absorption band at $1050 \mathrm{~cm}^{-1}, \mathrm{R} 400$ ) and TOC (Fig.4). In peatland, polysaccharides can represent up to $50 \%$ of the carbon from the native OM biomass (Laggoun-Défarge et al., 2008). In IR spectroscopy, polysaccharides contribute to several strong absorption bands, especially those culminating at $1050 \mathrm{~cm}^{-1}$ (vCO) and at $3345 \mathrm{~cm}^{-1}$ (vOH: Fig. 2), the former being more specific than the second one to 
which water and other organic groupings (e.g., $\mathrm{OH}$ of alcohols, $\mathrm{NH}$ of amines and amides) contribute. At both sites, the main polysaccharide IR absorption band at ca. $1050 \mathrm{~cm}^{-1}$ was strongly correlated to the OI parameter (Table 1; Fig. 4). This is fully consistent with the richness of these compounds in $\mathrm{O}$, especially when compared to aromatic and lipid moieties. Consequently, OI could be considered as a suitable parameter to follow polysaccharides decomposition in peat.

At the bog site HI was solely anti-correlated to the IR absorption band at $1710 \mathrm{~cm}^{-1}$, assigned to $v \mathrm{C}=\mathrm{O}$ vibration of carboxylic groups (Table 1 ; Fig. 4). In contrast, at the fen site, HI was correlated with most of the analysed IR absorption bands except for those at 3345 and 1611 $\mathrm{cm}^{-1}$ (Table 1; Fig. 4). Only the anti-correlation of HI with the IR absorption bands at 1710 $\mathrm{cm}^{-1}$ was common at both sites. These results did not indicate the same pattern than the one described by Zaccone et al. (2011) and Saenger et al. (2013) for peat and mineral soil, where lower HI values were mainly related to the highest degree of aromaticity of SOM. Additionally, the same authors indicated that a high HI implies a strong contribution of hydrogen rich compounds such as lipids. In our work on peat, lipidic and aromatic compounds were strongly and significantly correlated (Fig. 5). Consequently, the results of the present work did not allow us to rule out any impact of aromatic or lipidic compounds on HI but merely underlined that $\mathrm{HI}$ could be used as an index for decarboxylation processes in the course of peatification. In a previous study, Artz et al. (2008) demonstrated that in low pH environments such as peatlands, the increase in carboxylic contents is imputable to the release of free carboxylic acid groups in the course of peat decomposition. Conversely, Zaccone et al. (2008) reported a depth wise decrease of carboxylic acids together with a decrease of carbohydrate contents that they interpreted as a result of a progressive decarboxylation favoured by an important aerobic microbial activity (Sinsabaugh, 2010). Such patterns were not observed in the bog site where HI seemed independent of the IR absorption bands relative 
to polysaccharides, aromatic moieties and lipids (Table 1; Fig. 4). For this site, the anticorrelation of $\mathrm{HI}$ and the IR absorption band at $1710 \mathrm{~cm}^{1}$ cannot be explained straightforwardly. In contrast, in the fen site, the content of carboxylic acid varied simultaneously with polysaccharides, both these parameters decreasing with depth (Fig. 4). Such a trend highlighted decarboxylation during peat early diagenesis, as already described by Zaccone et al. (2008). If various studies had already underlined that OI and HI appeared as good indicators of the degree of SOM evolution (Disnar et al., 2003; Hetényi et al., 2006; Klavins et al., 2008; Lee, 2011), the present work provides evidences that (i) OI might be a suited parameter to infer carbohydrates in peat OM and (ii) that HI could at least roughly be used as an indicator of Sphagnum peat decarboxylation. Furthermore, the various links between $\mathrm{HI}$ and aromatic moieties and/or lipids did not allow ruling out a potential effect of aromatic and lipid on HI values. Then, to obtain more information about HI significance, we examined the shape of the multi-lobed S2 curve from which $\mathrm{HI}$ values are calculated $(\mathrm{HI}=$ S2/TOC $\times 100$, in mg hydrocarbons. ${ }^{-1}$ TOC).

\section{2. S2-derived parameters did not give additional information about peat OM} chemistry.

S2 curves obtained by pyrolysis of recent $\mathrm{OM}$ appear as multi-lobed signals corresponding to the successive cracking of several organic moieties. New parameters based on its shape and/or its integration, recently emerged as a complement of the previously discussed classical indicators. Parameters such as R400 and R330 arbitrarily divide the S2 curve into two distinct ranges of temperatures whereas mathematical deconvolution was performed to produce a set of individual Gaussian curves (F1, F2, F3 and F4) representative of the successive cracking of increasingly recalcitrant organic moieties (see Analytical section). In the present study and for 
both sites, R400 and R330 appeared strongly correlated to the IR absorption bands at 1050 $\mathrm{cm}^{-1}$ mainly imputable to polysaccharides (Table 1; Fig. 4). This is consistent with Gogo et al (2011) who showed a correlation between R400 and hemicellulosic content of peat. In our study on peat samples, as well as being previously demonstrated (Sebag et al., 2006; Tambach et al., 2009), most of the S2 signal could be explained by 4 components. Further interpretation of the so-called pyrolytic families corresponding to the four S2 signal components is based on the assumption that there is a direct link between OM temperature(s) of decomposition and its overall degree of diagenetic evolution (Disnar and Trichet, 1984). Accordingly, the components that cracked early during programmed pyrolysis can be considered as well preserved thermo-labile compounds whereas those that are decomposed later must be considered as more degraded/transformed and thermo-recalcitrant. Accordingly, when considering the $\mathrm{S} 2$ deconvolution results, the F1 and F2 components, respectively cracking at around $310^{\circ} \mathrm{C}$ and $350-360^{\circ} \mathrm{C}$, can be considered as sub-parts of the $\mathrm{R} 400$ parameter (Fig. 1). Because the R400 parameter was correlated to the IR band centred around $1050 \mathrm{~cm}^{-1}$, one could also expect the sum $\mathrm{F} 1+\mathrm{F} 2$ to correlate with this band attributed to polysaccharides. However, this is only partly the case. The F1 component is effectively correlated to the polysaccharide IR absorption band both at the bog and fen site (Table 1; Fig. 4), that is consistent with previous works (Disnar et al., 2003; Carrie et al., 2012). This suggests that the F1 family is predominantly composed of carbohydrates. In contrast, at both the bog and fen sites, the F2 component was not correlated to signals attributed to polysaccharides but with polyphenols and lipid IR absorption bands (Table 1; Fig. 4). Disnar et al (2003) showed that a part of the lignin cracks before $400^{\circ} \mathrm{C}$. This suggests that the $\mathrm{F} 2$ family may be composed of a mix of polymers dominated by polyphenol compounds, explaining (i) the lack of correlation between F2 and the polysaccharides IR band and (ii) the correlation with aromatic moieties IR 
band. These results are in good agreement with previous works on standard compounds (Carrie et al., 2012)

In mineral soil profiles the relative intensity increase with depth of the third component $(\mathrm{F} 3)$ had been generally attributed to increasing proportions with depth of the so-called "humic substances" (Disnar et al., 2003; Hetenyi et al., 2006; Sebag et al., 2006). In the present work, the intensity of the F3 signal of samples from the bog site appeared well correlated to the intensity of the IR absorption band at $1710 \mathrm{~cm}^{-1}$ (Table 1; Fig. 4). In the fen site, no correlation was found between F3 and any of the IR absorption bands. F4, the last component of the $\mathrm{S} 2$ curve appears between 450 and $550^{\circ} \mathrm{C}$ in our experimental conditions. In the bog site F4 is significantly correlated with the IR absorption band at $1611 \mathrm{~cm}^{-1}$ attributable to aromatic carbon (Table 1; Fig. 4). Additionally, in the fen site, F4 appears either correlated or anti-correlated with all identified IR absorption bands except the IR absorption bands at 1611 $\mathrm{cm}^{-1}$ (Table 1; Fig. 4). Accordingly, F1, F2, F3 and F4 did not give further insights on the biogeochemical properties of peat since their significance (i) was redundant with classical RE parameters or (ii) did not give univocal biogeochemical assignment.

These results emphasised the current limitations of RE pyrolysis to investigate the chemical composition of peat by the way of S2 pyrolysis curve analysis. Practically, this also entails some contradictory results between RE parameters. For example, F2 and F3 components appeared correlated in the bog site whereas that was not the case in the fen site, thus indicating two distinct biogeochemical significations (Fig. 4). These drawbacks might originate, partially, from the already assumed distinctive interactions between plant precursors and downward decomposition dynamics at the bog and fen sites (Delarue et al., 2011). Moreover, Carrie et al. (2012) using RE pyrolysis to investigate biochemical composition of several standards indicated that proteins, lipids, lignins/polyphenols and carbohydrates all cracked within a small range of temperatures. Thus, depending on the distribution of these 
organic compounds in 'natural' SOM and their relative changes in the course of diagenesis processes, the significance of the S2-derived parameters may vary considerably. In our study, the lack of mineral phases avoided any interactions with OM in contrast to study on mineral soils. Indeed, it was demonstrated that matrix mineralogy strongly influenced the OI and HI, the latter being calculated from the pyrolysis S2 curve (Katz et al., 1983). Furthermore, secondary reactions upon RE pyrolysis RE have been scantly investigated, although these reactions are well-known to affect carbohydrates or lignin in most pyrolytic techniques (Saiz-Jimenez, 1994; Murwanashyaka et al., 2001; Templier et al., 2005). In fact, Sanei et al. (2005) demonstrated that the rate of heating and the sample residence time were not sufficient to allow the thermal decomposition of the pyrolysis secondary compounds. Thus, F3 and F4 likely contain higher contents of secondary reactions (or artifacts) than F1 and F2, which may distort the significance of compounds "normally" attributed to these fractions. As a part of the S2 pyrolysis curve, F3 and F4 were therefore likely to affect the HI significance explaining, at least partially, differences between the bog and fen sites. Therefore, our work suggested that an effort must be done to quantify the impact of secondary reactions upon RE pyrolysis parameters. Taken together, these conclusions underlined the need to better constrain RE pyrolysis application to SOC by (i) the study of the impact of interaction between OM composition and mineral phases on RE-derived parameters or by (ii) systematically combining RE routine use with another tool such as FTIR.

\section{Conclusions}

The (bio-)chemical significance of RE pyrolysis derived parameters was investigated by FTIR spectroscopy in order to evaluate the potential of this technique as an indicator of the composition of peat OM. This was performed on peat cores from two contrasting 
environmental situations distinguished by their moisture conditions. According to statistical analysis of the RE and IR data the classical parameters OI and HI could be taken as indicators of the polysaccharide content and of decarboxylation processes, respectively. S2 signal deconvolution into Gaussian-like curves is satisfactorily achieved with only four components for the studied peat samples, as it has already been proven to be adequate for mineral soils. However, it also appeared clearly that parameters derived from the S2 pyrolysis curve (namely R400, R330, F1 to F4 components obtained by S2 deconvolution) did not give clear and useful complementary information on the peat composition and on compositional changes. The main reason is that different (bio-) chemical components might contribute to a single component of the S2 signal thus making difficult or even impossible any biochemical interpretation of this pyrolysis signal. Moreover, the impact of pyrolysis secondary reactions is not fully known and is a s major draw-backs on the use of the pyrolysis curve S2.

Here, we underlined some of the strong limitations of RE analytical pyrolysis for the characterization of the biochemistry of peat OM. Finally, this emphasizes the need to combine this technique with other tools, such as FTIR, to avoid any major misinterpretation. Such conclusions can also, by extension, be applied to mineral soils where biochemical composition of OM depends (i) on a wider range of organic compounds and (ii) on various stabilization mechanisms which may interact to change RE-derived parameters significance.

\section{Acknowledgements}

This research is a contribution of the ANR PEATWARM project (Effect of moderate warming on the functioning of Sphagnum peatlands and their function as carbon sink).

PEATWARM is supported by the French National Agency for Research under the "Vulnerability: Environment-Climate" Program (ANR-07-VUL-010). We gratefully 
acknowledge Marielle Hatton and Rachelle Boscardin for analytical assistance. Authors are also grateful to the reviewers and Clifford C. Walters for their constructive comments and helpful suggestions on earlier version of the manuscript

\section{References}

Artz, R.R.E., Chapman, S.J., Robertson, A.H.J., Potts, J.M., Laggoun-Defarge, F., Gogo, S., Comont, L., Disnar, J.R., Francez, A.J., 2008. FTIR spectroscopy can be used as a screening tool for organic matter quality in regenerating cutover peatlands. Soil Biology \& Biochemistry 40, 515-527.

Carrie, J., Sanei, H., Stern, G., 2012. Standardisation of Rock-Eval pyrolysis for the analysis of recent sediments and soils. Organic Geochemistry 46, 38-53.

Clymo, R.S., 1983. Peat. In: Gore, A.J.P. (Ed.), Ecosystems of the World, 4A. Mires: Swamp, Bog, Fen and Moor, General Studies. Elsevier, Amsterdam, pp. 159-224.

Cocozza, C., D'Orazio, V., Miano, T.M., Shotyk, W., 2003. Characterization of solid and aqueous phases of a peat bog profile using molecular fluorescence spectroscopy, ESR and FTIR, and comparison with physical properties. Organic Geochemistry 34, 49-60.

Davidson, E.A., Janssens, I.A., 2006. Temperature sensitivity of soil carbon decomposition and feedbacks to climate change. Nature 440, 165-173.

Delarue, F., Laggoun-Defarge, F., Disnar, J.R., Lottier, N., Gogo, S., 2011. Organic matter sources and decay assessment in a Sphagnum-dominated peatland (Le Forbonnet, Jura Mountains, France): impact of moisture conditions. Biogeochemistry 106, 39-52.

Di-Giovanni, C., Disnar, J.R., Bichet, V., Campy, M., Guillet, B., 1998. Geochemical characterization of soil organic matter and variability of a postglacial detrital organic supply (Chaillexon Lake, France). Earth Surface Processes and Landforms 23, 1057-1069. 
Disnar, J.R., Trichet, J., 1984. The influence of various divalent cations $\left(\mathrm{UO}_{2}^{2+}, \mathrm{Cu}^{2+}, \mathrm{Pb}^{2+}\right.$, $\left.\mathrm{Co}^{2+}, \mathrm{Ni}^{2+}, \mathrm{Zn}^{2+}, \mathrm{Mn}^{2+}\right)$ on thermally induced evolution of organic matter isolated from an algal mat. Organic Geochemistry 6, 865-874.

Disnar, J.R., Guillet, B., Keravis, D., Di-Giovanni, C., Sebag, D., 2003. Soil organic matter (SOM) characterization by Rock-Eval pyrolysis: scope and limitations. Organic Geochemistry $34,327-343$.

Dorrepaal, E., Toet, S., van Logtestijn, R.S.P., Swart, E., van de Weg, M.J., Callaghan, T.V., Aerts, R., 2009. Carbon respiration from subsurface peat accelerated by climate warming in the subarctic. Nature 460, 616-679.

Espitalie, J., Deroo, G., Marquis, F., 1985a. Rock-Eval pyrolysis and its application .2. Revue de l’Institut Français du pétrole 40, 755-784.

Espitalie, J., Deroo, G., Marquis, F., 1985b. Rock-Eval pyrolysis and its applications. Revue de l'Institut Français du pétrole 40, 563-579.

Feller, C., Brossard, M., Chen, Y., Landa, E.R., Trichet, J., 2010. Selected pioneering works on humus in soils and sediments during the 20th century: A retrospective look from the International Humic Substances Society view. Physics and Chemistry of the Earth 35, 903912.

Gogo, S., Laggoun-Defarge, F., Delarue, F., Lottier, N., 2011. Invasion of a Sphagnumpeatland by Betula spp and Molinia caerulea impacts organic matter biochemistry. Implications for carbon and nutrient cycling. Biogeochemistry 106, 53-69.

Gorham, E., 1991. Northern peatlands - role in the carbon-cycle and probable responses to climatic warming. Ecological Applications 1, 182-195.

Hetenyi, M., Nyilas, T., Sajgo, C., Brukner-Wein, A., 2006. Heterogeneous organic matter from the surface horizon of a temperate zone marsh. Organic Geochemistry 37, 1931-1942. 
Hetenyi, M., Nyilas, T., Toth, T.M., 2005. Stepwise Rock-Eval pyrolysis as a tool for typing heterogeneous organic matter in soils, 16th International Symposium on Analytical and Applied Pyrolysis. Elsevier Science Bv, Alicante, Spain, pp. 45-54.

Holtvoeth, J., Kolonic, S., Wagner, T., 2005. Soil organic matter as an important contributor to late Quaternary sediments of the tropical West African continental margin. Geochimica Et Cosmochimica Acta 69, 2031-2041.

Intergovernmental Panel on Climate Change (IPCC), 2007. Climate Change 2007: The Physical Science Basis. Cambridge University Press.

Jassey, V.E.J., Chiapusio, G., Mitchell, E.A.D., Binet, P., Toussaint, M.L., Gilbert, D., 2011. Fine-Scale Horizontal and Vertical Micro-distribution Patterns of Testate Amoebae Along a Narrow Fen/Bog Gradient. Microbial Ecology 61, 374-385.

Katz, B.J., 1981. Limitations of rock-eval pyrolysis for typing organic-matter. American Association of Petroleum Geologists Bulletin 65, 944-944.

Klavins, M., Sire, J., Purmalis, O., Melecis, V., 2008. Approaches to estimating humification indicators for peat. Mires and Peat 3,15p.

Lafargue, E., Marquis, F., Pillot, D., 1998. Rock-Eval 6 applications in hydrocarbon exploration, production and soil contamination studies. Revue de l'Institut Français du Pétrole $53,421-437$.

Laggoun-Defarge, F., Mitchell, E., Gilbert, D., Disnar, J.R., Comont, L., Warner, B.G., Buttler, A., 2008. Cut-over peatland regeneration assessment using organic matter and microbial indicators (bacteria and testate amoebae). Journal of Applied Ecology 45, 716-727. Lee, H.T., 2011. Analysis and characterization of samples from sedimentary strata with correlations to indicate the potential for hydrocarbons. Environmental Earth Sciences 64, 1713-1728. 
Miras, Y., Laggoun-Défarge, F., Guenet, P., Richard, H., 2004. Multi-disciplinary approach to changes in agro-pastoral activities since the Sub-Boreal in the surroundings of the " narse d'Espinasse » (Puy de Dôme, French Massif Central). Vegetation History and Archaeobotany $13,91-103$.

Murwanashyaka, J.N., Pakdel, H., Roy, C., 2001. Step-wise and one-step vacuum pyrolysis of birch-derived biomass to monitor the evolution of phenols. Journal of Analytical and Applied Pyrolysis 60, 219-231.

Otto, A., Otto, F.E.L., Boucher, O., Church, J., Hegerl, G., Forster, P.M., Gillett N.P., Gregory, J., Johnson, G.C., Knutti, R., Lewis, N., Lohmann, U., Marotzke, J., Myhre, G., Shindell, D., Stevens, B., Allen, M.R., 2013. Energy budget constraints on climate response. Nature Geoscience 6, 415-416.

Rasmussen, S., Wolff, C., Rudolph, H., 1995. Compartmentalization of phenolic constituents in sphagnum. Phytochemistry $38,35-39$.

Saenger, A., Cecillon, L., Sebag, D., Brun, J.J., 2013. Soil organic carbon quantity, chemistry and thermal stability in a mountainous landscape: A Rock-Eval pyrolysis survey. Organic Geochemistry 54, 101-114.

Saiz-Jimenez, C., 1994. Analytical pyrolysis of humic substances - pitfalls, limitations, and possible solutions. Environmental Science \& Technology 28, 1773-1780.

Sanei, H., Stasiuk, L.D., Goodarzi, F., 2005. Petrological changes occurring in organic matter from Recent lacustrine sediments during thermal alteration by Rock-Eval pyrolysis. Organic Geochemistry 36, 1190-1203.

Sebag, D., Disnar, J.R., Guillet, B., Di Giovanni, C., Verrecchia, E.P., Durand, A., 2006. Monitoring organic matter dynamics in soil profiles by 'Rock-Eval pyrolysis': bulk characterization and quantification of degradation. European Journal of Soil Science 57, 344355. 
Sinsabaugh, R.L., 2010. Phenol oxidase, peroxidase and organic matter dynamics of soil. Soil Biology \& Biochemistry 42, 391-404.

Solomon, D., Lehmann, J., Kinyangi, J., Liang, B.Q., Schafer, T., 2005. Carbon K-edge NEXAFS and FTIR-ATR spectroscopic investigation of organic carbon speciation in soils. Soil Science Society of America Journal 69, 107-119.

Sykes, R., Snowdon, L.R., 2002. Guidelines for assessing the petroleum potential of coaly source rocks using Rock-Eval pyrolysis. Organic Geochemistry 33, 1441-1455.

Tambach, T.J., Veld, H., Griffioen, J., 2009. Influence of HCl/HF treatment on organic matter in aquifer sediments: A Rock-Eval pyrolysis study. Applied Geochemistry 24, 2144-2151.

Tamburini, F., Adatte, T., Follmi, K., Bernasconi, S.M., Steinmann, P., 2003. Investigating the history of East Asian monsoon and climate during the last glacial-interglacial period (0140000 years): mineralogy and geochemistry of ODP Sites 1143 and 1144, South China Sea. Marine Geology 201, 147-168.

Templier, J., Derenne, S., Croue, J.P., Largeau, C., 2005. Comparative study of two fractions of riverine dissolved organic matter using various analytical pyrolytic methods and a C-13 CP/MAS NMR approach. Organic Geochemistry 36, 1418-1442.

Vanbreemen, N., 1995. How sphagnum bogs down other plants. Trends in Ecology \& Evolution 10, 270-275.

von Lutzow, M., Kogel-Knabner, I., Ekschmittb, K., Flessa, H., Guggenberger, G., Matzner, E., Marschner, B., 2007. SOM fractionation methods: Relevance to functional pools and to stabilization mechanisms. Soil Biology \& Biochemistry 39, 2183-2207.

Zaccone, C., Said-Pullicino, D., Gigliotti, G., Miano, T.M., 2008. Diagenetic trends in the phenolic constituents of Sphagnum-dominated peat and its corresponding humic acid fraction. Organic Geochemistry 39, 830-838. 
Zaccone, C., Sanei, H., Outridge, P.M., Miano, T.M., 2011. Studying the humification degree and evolution of peat down a Holocene bog profile (Inuvik, NW Canada): A petrological and chemical perspective. Organic Geochemistry 42, 399-408.

\section{Figure captions}

Figure 1: Examples of $\mathrm{S} 2$ curves produced by RE pyrolysis and mathematical treatments proposed for their interpretation: (A) R400 and R330 integration areas (respectively AR400 and AR330) (B) S2 mathematical deconvolution into four components.

Figure 2: (A) FTIR spectrum of a peat sample (B) and assignment of the main absorption bands (from Cocozza et al., 2003 and Artz et al., 2008)

Figure 3: Principal component analysis biplots (axes 1 and 2 namely PCA1 and PCA2). Samples are indicated as follows: triangles for acrotelm, circle for mesotelm and squares for catotelm in the bog (A) and the fen (B) sites.

Figure 4: Bi-plots of principal components analysis (PCA1 and PCA2) of peat characterization by RE pyrolysis and FTIR spectroscopy in the bog (A) and (B) the fen sites.

Figure 5: Correlation between the normalized intensities of the $2918 \mathrm{~cm}^{-1}$ (Antisymmetric $\mathrm{CH}_{2}$; lipids) and $1611 \mathrm{~cm}^{-1}$ (C=C stretching; aromatic compounds) FTIR absorption bands. 

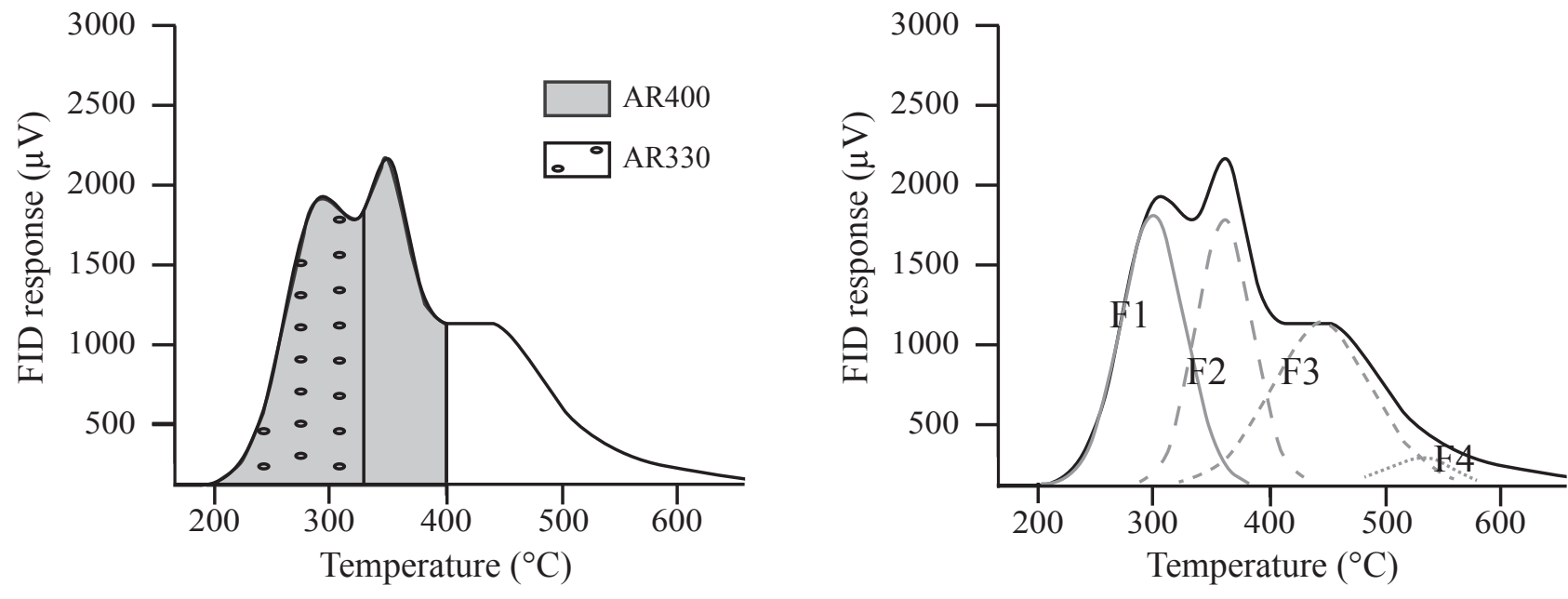

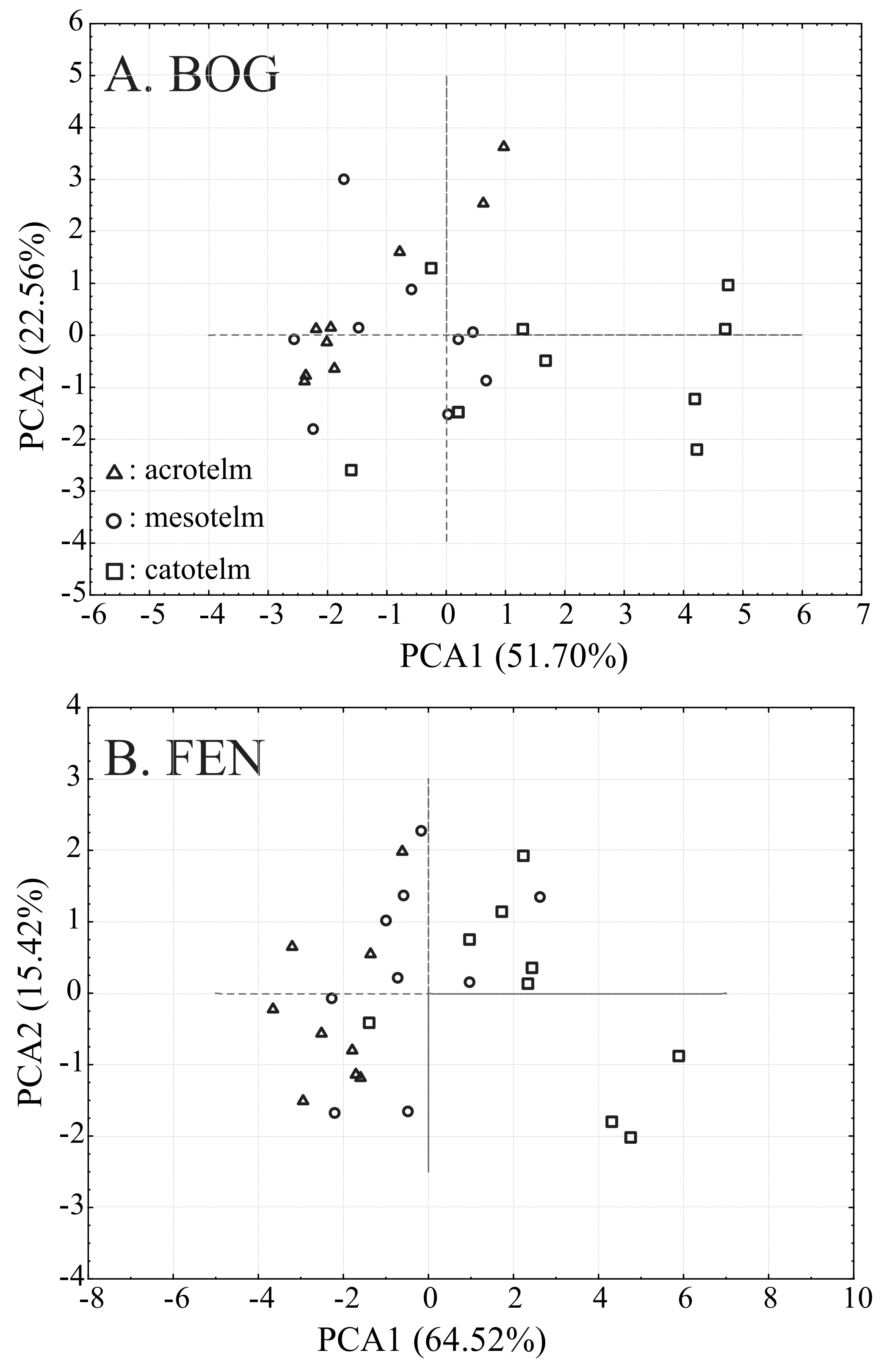
A.

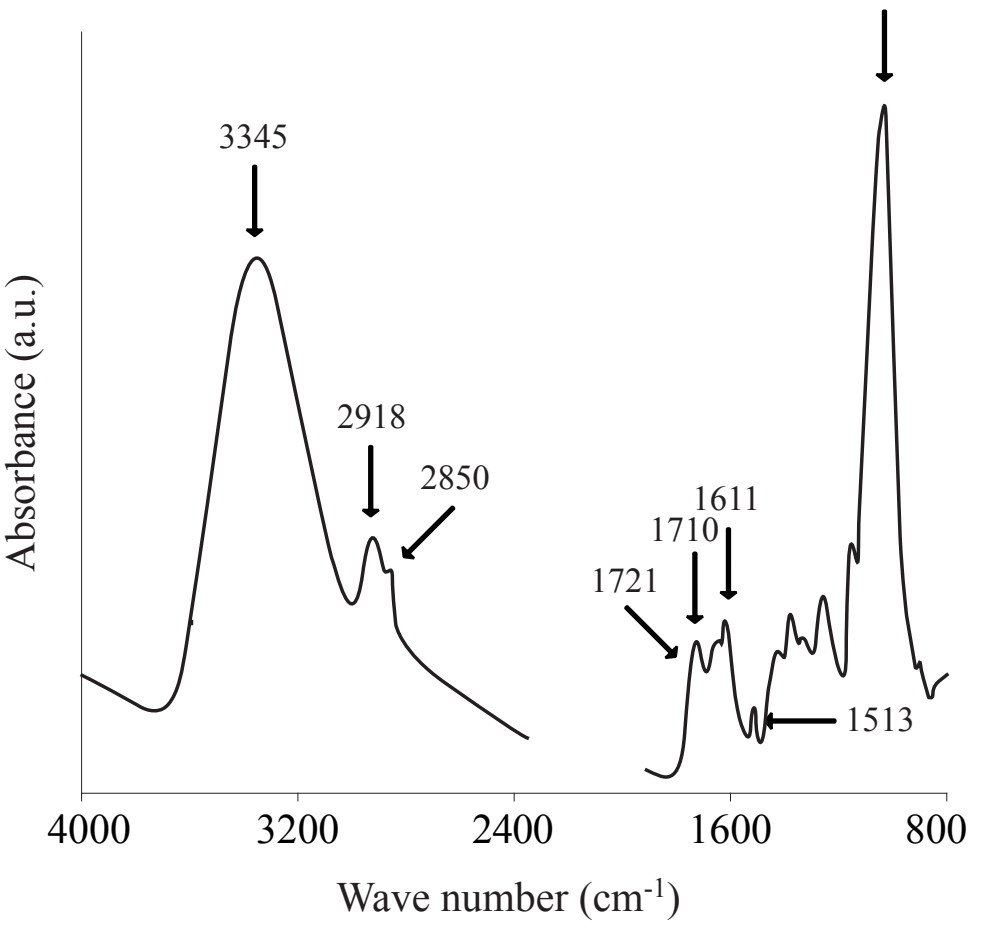

B.

3345: $\gamma(\mathrm{O}-\mathrm{H})$ stretching; cellulose

2918: Antisymmetric $\mathrm{CH}_{2}$; lipids

2850: Symmetric $\mathrm{CH}_{2}$; lipids

1721: $\mathrm{C}=\mathrm{O}$ stretch of $\mathrm{COOH}$ or $\mathrm{COOR}$; carbonyl (carboxylate)

1710: $\mathrm{C}=\mathrm{O}$ stretch of $\mathrm{COOH}$; carbonyl (carboxylic acids)

1611: $\mathrm{C}=\mathrm{C}$ stretching; aromatic compounds

1513: $\mathrm{C}=\mathrm{C}$; aromatic compounds

1050: Combination of $\mathrm{C}-\mathrm{O}$ stretching and $\mathrm{OH}$ deformation; polysaccharides 

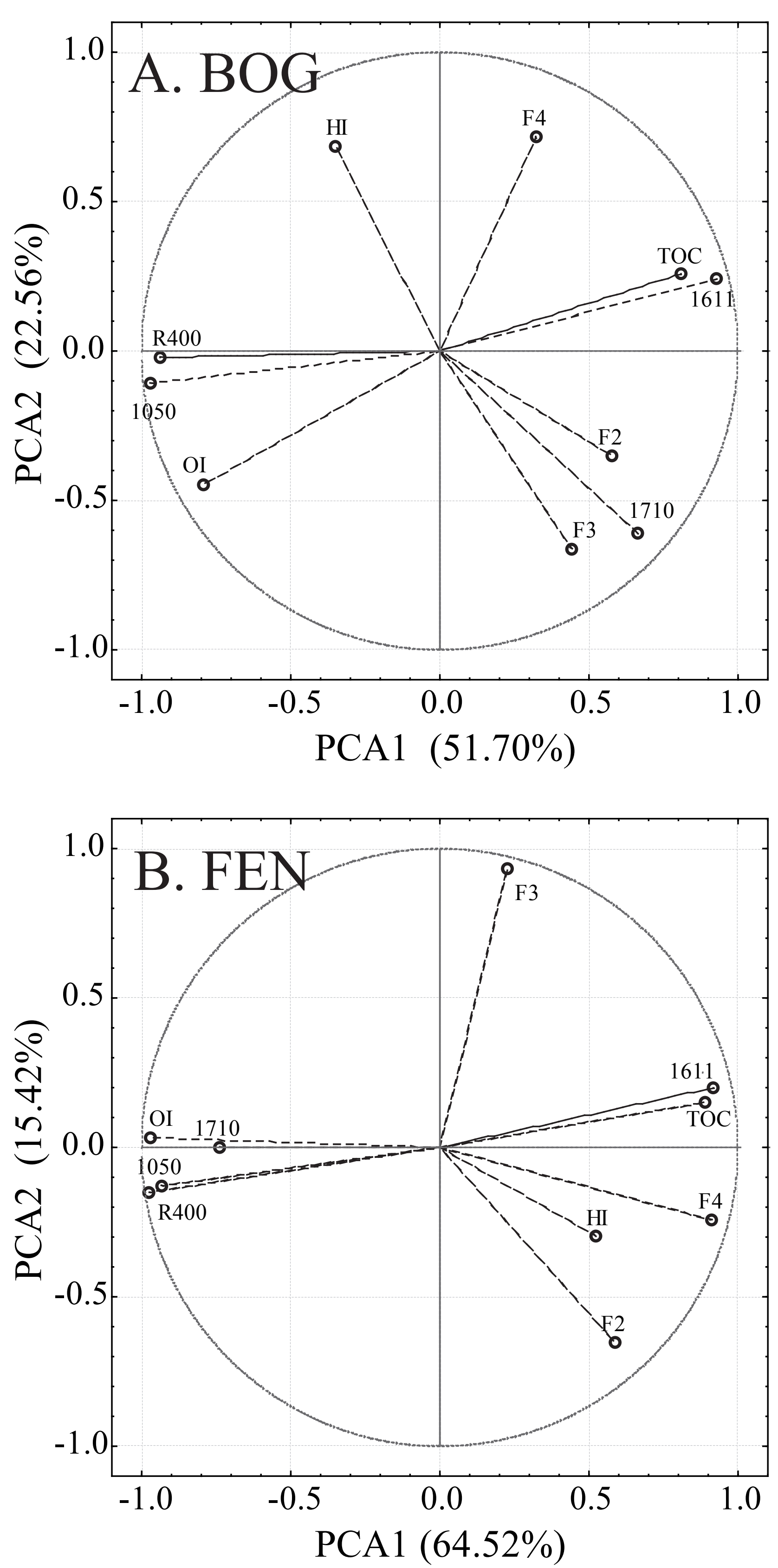


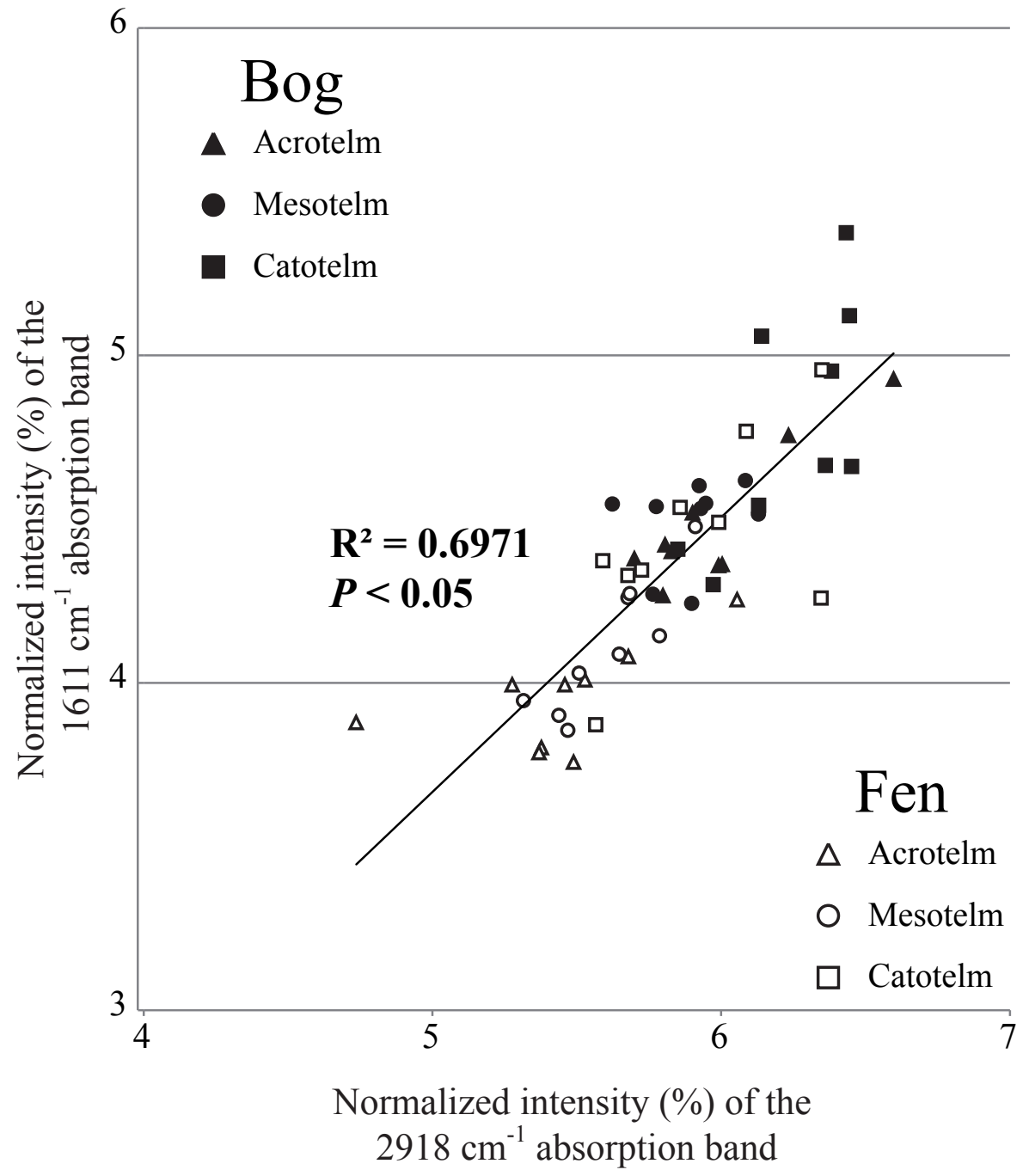




\section{Table}

Table 1: Correlation matrix of the studied variables. All significant values $(P<0.05)$ are indicated by a correlation coefficient in bold characters $(n=27$ for each site).

Rock-Eval parameters

\begin{tabular}{|c|c|c|c|c|c|c|c|c|c|c|}
\hline \multirow{2}{*}{\multicolumn{2}{|c|}{ A : Bog site }} & \\
\hline & & $T O C$ & $O I$ & $H I$ & $R 400$ & $R 330$ & $F 1$ & $F 2$ & $F 3$ & F4 \\
\hline & 3345 & $-0,54$ & 0,63 & 0,2 & $\mathbf{0 , 7 3}$ & 0,54 & 0,48 & $-0,41$ & $-0,23$ & $-0,22$ \\
\hline & 2918 & 0,71 & $-0,74$ & $-0,12$ & $-0,75$ & $-0,72$ & $-0,49$ & 0,26 & 0,35 & 0,33 \\
\hline & 2850 & 0,77 & $-0,71$ & $-0,13$ & $-0,68$ & $-0,67$ & $-0,47$ & 0,33 & 0,24 & 0,36 \\
\hline & 1721 & $-0,13$ & 0,2 & $-0,29$ & $-0,34$ & $-0,07$ & $-0,55$ & $0, \mathbf{4 3}$ & 0,43 & $-0,16$ \\
\hline & 1710 & 0,28 & $-0,16$ & $-0,53$ & & & & 0,61 & 0,64 & $-0,15$ \\
\hline & 1611 & 0,79 & $-0,79$ & $-0,06$ & $-0,89$ & $-0,85$ & $-0,55$ & 0,4 & 0,27 & 0,41 \\
\hline & 1513 & $\mathbf{0 , 8 2}$ & $-0,77$ & $-0,33$ & $-0,82$ & $-0,59$ & $-0,62$ & 0,46 & 0,36 & 0,25 \\
\hline & 1050 & $-0,85$ & 0,8 & 0,27 & $\mathbf{0 , 8 8}$ & 0,75 & 0,64 & $-0,48$ & $-0,35$ & $-0,35$ \\
\hline
\end{tabular}

B: Fen site

Rock-Eval parameters

\begin{tabular}{|c|c|c|c|c|c|c|c|c|c|}
\hline & TOC & $O I$ & $H I$ & $R 400$ & $R 330$ & $F 1$ & $F 2$ & $F 3$ & $F 4$ \\
\hline 3345 & $-0,66$ & 0,61 & $-0,08$ & 0,63 & 0,47 & 0,62 & $-0,48$ & $-0,17$ & $-0,61$ \\
\hline 2918 & 0,69 & $-0,79$ & 0,66 & $-\mathbf{0 , 8 3}$ & $-0,76$ & $-0,64$ & 0,34 & 0,23 & 0,72 \\
\hline 2850 & $\mathbf{0 , 7 0}$ & $-0,78$ & 0,58 & $-0,82$ & $-0,73$ & $-0,65$ & 0,36 & 0,24 & 0,70 \\
\hline 1721 & $-0,66$ & $\mathbf{0 , 8 2}$ & $-0,51$ & $\mathbf{0 , 8 0}$ & 0,76 & 0,71 & $-0,41$ & $-0,29$ & $-0,66$ \\
\hline 1710 & $-\mathbf{0 , 5 8}$ & 0,72 & $-0,54$ & 0,69 & & 0,59 & $-0,39$ & $-0,21$ & $-0,57$ \\
\hline 1611 & $\mathbf{0 , 8 1}$ & $-0,85$ & 0,26 & $-0,93$ & $-0,85$ & $-0,84$ & 0,45 & 0,35 & $\mathbf{0 , 8 2}$ \\
\hline 1513 & 0,82 & $-0,94$ & 0,48 & $-0,93$ & $-0,85$ & $-0,80$ & 0,59 & 0,21 & $\mathbf{0 , 8 7}$ \\
\hline 1050 & $-0,79$ & $\mathbf{0 , 8 8}$ & $-0,41$ & 0,93 & 0,86 & $\mathbf{0 , 8 1}$ & $-0,48$ & $-0,30$ & $-0,8$ \\
\hline
\end{tabular}

